\title{
Influence of Displacements on Calculus of the Longitudinal Modulus of Elasticity of Pinus Caribaea Structural Round Timber Beams
}

\author{
André Luis Christoforo ${ }^{1, *}$, Francisco Antonio Rocco Lahr ${ }^{2}$, Elen Aparecida Martines Morales ${ }^{3}$, André \\ Luiz Zangiácomo ${ }^{4}$, Túlio Hallak Panzera ${ }^{1}$
}

\begin{abstract}
${ }^{1}$ Department of Mechanical Engineering, Federal University of São João del-Rei (UFSJ), São João del-Rei, 36307-352, Brazil
${ }^{2}$ Department of Structural Engineering, University of São Paulo (EESC/USP), São Carlos, 13566-590, Brazil

${ }^{3}$ Department of Wood Engineering, São Paulo State University, Experimental Campus of Itapeva, Itapeva, 18409-010, Brazil

${ }^{4}$ Department of Engineering, Federal University of Lavras (UFLA), Lavras, 37200-000, Brazil
\end{abstract}

\begin{abstract}
Round timber shows great potential for use as a building material, having the advantage of not being processed, such as the sawn wood. In Brazil, the normative standards that deal with the existing round timber elements are mainly headed for the pole market, being in force for at least twenty years without technical review, recommending characterization of this material by destructive methods, using small specimens with no defects and a cantilever beam structural model[2]. This paper aims to determine the longitudinal modulus of elasticity of Pinus caribaea structural round timber beams using static three-point bending test under physical and geometrical linearity conditions (non-destructive methodology) which evaluates the effect of the $\mathrm{L} / 200$ and $\mathrm{L} / 300$ displacement measurements for this purpose[6]. The results achieved by the confidence interval show the statistical equivalence between the values of the modulus of elasticity, being possible in this case, the use of both limits in displacement measurements.
\end{abstract}

Keywords Round timber, three-point static bending, longitudinal modulus of elasticity

\section{Introduction}

The use of wood as a structural element in Brazil has grown over the last years due to researches headed for turning it into a more competitive material in comparison with other materials used in structure construction, such as steel and concrete([1]). However, the existence of gaps in the national standards combined with the lack of knowledge by building professionals about its mechanical properties contribute to limit its potential for use in constructions, being found mostly in the form of struts, concrete formworks and so on.

Among the many solutions wood can offers its outstanding use as natural or round form, having the great advantage of not being processed, as it is the case of sawn wood, which can work as structural elements such as beams, columns, aerial electric distribution poles and others. However, the national standard that deal with round timber elements are mainly headed for the pole market, being in force for at least twenty years without technical revision.

The Brazilian standard NBR 6231[2] prescribes the

* Corresponding author:

alchristoforo@yahoo.com.br (André Luis Christoforo)

Published online at http://journal.sapub.org/ijaf

Copyright (c) 2012 Scientific \& Academic Publishing. All Rights Reserved clamped cantilever beam model for the calculus of the longitudinal modulus of elasticity, which is a destructive method.

The Brazilian standard NBR 8456[3] only sets conditions for preparing and receiving Eucalyptus poles preserved under pressure, which is commonly used in overhead power distribution networks.

The Brazilian standard NBR 8457[4] describes poles of preserved Eucalyptus to be used in overhead power distribution networks, specifying the pole length, type, nominal strength, maximum deflection, length among others.

Technical standard NBR 6122[5] recommends the use of standard NBR 7190[6] to calculate the strength of timber piles, the latter being limited to destructive tests using small and clear specimens, even being convenient the use of the structural piece to determine their mechanical properties.

In countries where wood is traditionally used, it is possible to find a wide range of standards for many different purposes. Not only, the extensively use of wood through years but also the research experiences contribute to the large amount of information found in those documents.

Characterization, specification and standardization of experimental methods for structural-sized pieces of wood are usually done based on international standards[7-11]. According to these standards, the modulus of elasticity can be calculated by either using three and four point bending or 
clamped cantilever beam methods. It is noteworthy that equations used to determine the modulus of elasticity of round elements consider the hypothesis of truncated-conical geometry, based on one or two circumference values which are used to calculate its moment of inertia.

With focus on the use and study of strength and stiffness properties of structural round timber, a number of studies can be mentioned[12-23].

Miná[22] has shown a theoretical and experimental study of timber piles, including the instrumentation for timber pile foundations of a wooden bridge, in order to generate design recommendations for short-span wooden bridges. An equation to calculate the modulus of elasticity of round elements based on the Virtual Work Principle (VWP) was also presented, considering the basis, medium and top diameter values measured along the piece.

Zangiácomo and Rocco[23] evaluated the L/D ratio between length (L) and diameter (D) for correctly applying the Euler-Bernoulli theory beam to Pinus elliottii and Pinus caribea round timber structural elements, finding acceptable ratios of 12 and 15 respectively. Pinus pieces showing these ratios or higher values are free from shear influence on the deflection calculus.

Characterization of structural-sized wood elements was also performed by non-destructive tests, aimed at determining the physical and mechanical properties of a structural element without changing its usability[14]. Non-destructive testing has the advantage of not needing specimen extraction, enabling the study of its structural integrity[24,25], which is normally done by transverse vibration and ultrasound techniques[26-35].

As explained above, normative characterization of round wood structural pieces is carried out by using destructive methods. Non-destructive methods are basically ultrasound and transverse vibration, which do not require the use of mechanical testing. This study aims to present a non-destructive approach to determine the longitudinal modulus of elasticity of round timber structural beams, based on the three-point static bend testing under small-displacement conditions. The $L / 200$ and $L / 300$ ratios were used as displacement limiting values, being $L$ the pieces length, expressed in centimetre $(\mathrm{cm})$.

\section{Materials and Methods}

In order to determine the longitudinal modulus of elasticity, 16 round pieces of Pinus caribaea were used, having an average length of $580 \mathrm{~cm}$ and an average taper of 0.01 .

Round pieces obey the $L / D_{e q} \geq 21$ ratio[23] to validate the use of the Euler-Bernoulli beam theory, being L the length and $D_{e q}$ the equivalent diameter, measured at the midpoint of the element, assuming that the sections are perfectly circular, the diameters vary linearly along its length and the maximum displacement of the element which occurs at the point of application of the force (small taper).

In this study, the modulus of elasticity is calculated by
Equation 1, which is derived from the three-point static bending structural model (Figure 1), adapted from Brazilian standard[6] for circular section structural pieces, neglecting the load and displacement variations, being $(\mathrm{F})$ the force found for the $(\delta) \mathrm{L} / 300$ and $\mathrm{L} / 200$ displacements. It must be highlighted that the $\mathrm{L} / 200$ ratio is the measurement defined by standard[6] that ensures physical and geometrical linearity for wooden pieces (small displacement), whereas the $\mathrm{L} / 300$ is a more conservative measurement, quoted to replace the $\mathrm{L} / 200$ measurement in the new version of standard[6].

$$
E=\frac{4 \cdot F \cdot L^{3}}{3 \cdot \pi \cdot \delta \cdot D_{e q}{ }^{4}}
$$

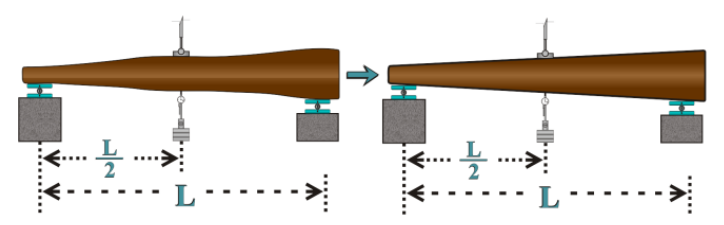

Figure 1. Three-point static bending test

Statistical equivalence between the values found from $E_{L / 300}$ (longitudinal modulus of elasticity calculated for the $L / 300$ measurement) and $E_{L / 200}$ (longitudinal modulus of elasticity calculated for the $L / 200$ measurement) for structural round timber is evaluated by using a confidence interval for the medians, which is expressed by Equation 2, being $\mu$ the difference between population means, $\bar{x}_{m}$ the difference between sample means, $n$ the sample size, $S_{m}$ the difference between sample standard deviations, and $t_{\alpha / 2, n-1}$ the tabulated value from Student's t-distribution with $n-1$ degrees of freedom and significance level $\alpha$.

$$
\bar{x}_{m}-t_{\alpha / 2, n-1} \cdot S_{m} / \sqrt{n} \leq \mu \leq \bar{x}_{m}+t_{\alpha / 2, n-1} \cdot S_{m} / \sqrt{n}
$$

Anderson-Darling test was used to see whether the sets of values for the modulus of elasticity were normally distributed, validating the confidence interval presented herein.

\section{Results and Conclusions}

The moduli of elasticity of $E_{L / 300}$ and $E_{L / 200}$ founded for Pinus caribaea structural round timber are shown in Table 1.

Table 1. $E_{L / 300}$ e $E_{L / 200}$ values.

\begin{tabular}{cccccc}
\hline Peças & $E_{L / 300}(\mathrm{MPa})$ & $E_{L / 200}(\mathrm{MPa})$ & Peças & $E_{L / 300}(\mathrm{MPa})$ & $E_{L / 200}(\mathrm{MPa})$ \\
\hline 1 & 6324 & 6819 & 10 & 6502 & 6102 \\
2 & 8689 & 8355 & 11 & 9527 & 9121 \\
3 & 9521 & 9931 & 12 & 8675 & 8972 \\
4 & 8783 & 8466 & 13 & 8322 & 8056 \\
5 & 7468 & 7927 & 14 & 6584 & 6936 \\
6 & 7430 & 7889 & 15 & 10206 & 9570 \\
7 & 8257 & 7693 & 16 & 9481 & 9079 \\
8 & 7688 & 7920 & 17 & 6539 & 6924 \\
9 & 7321 & 6839 & 18 & 5820 & 5977 \\
\hline
\end{tabular}

P-values founded for the moduli of elasticity $E_{L / 300}$ and $E_{L / 200}$ are respectively 0.521 and 0.679 , both greater than 0.05 , confirming the hypothesis of normal distribution and validating the use of the confidence interval[36], as shown in Figure 2 . 


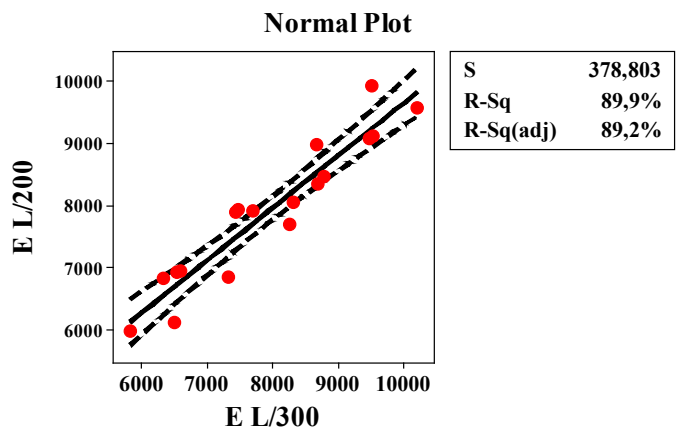

Figure 2. Normal plot between $E_{L / 300}$ e $E_{L / 200}$

The graph of linear regression between the elasticity values for the two displacement limits is shown in Figure 3, whose adjustment equation and correlation coefficient $\left(R^{2}\right)$ are respectively $r(x)=0.85 \cdot x+1201.11$ and 0.89 .

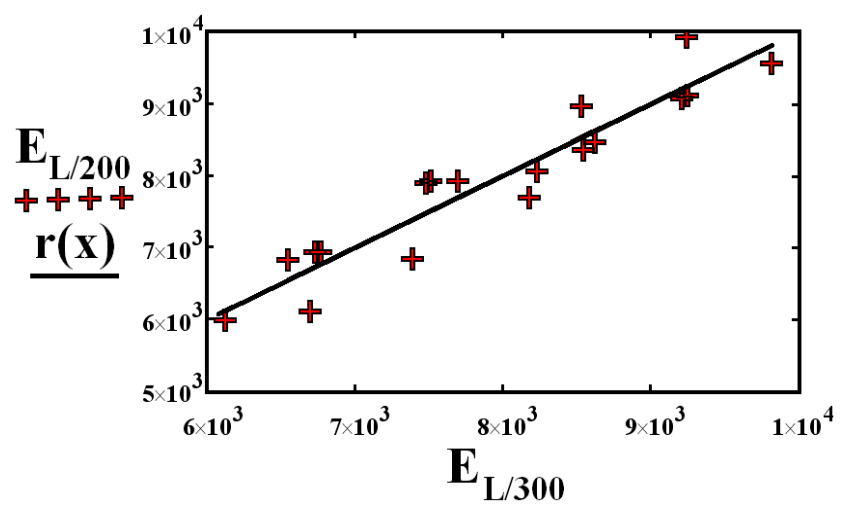

Figure 3. Linear regression between $E_{L / 300}$ e $E_{L / 200}$

The confidence interval between $E_{L / 300}$ and $E_{L / 200}$ is $-800.45 \leq \mu \leq 862.77$, being statistically equivalent by the relevance of zero to the subset founded. This implies that static three-point bending testing combined with the use of Equation 1 under the $L / 300$ and $L / 200$ displacement conditions led to equivalent values for the modulus of elasticity of the evaluated timbers. This result cannot be extended to other wood species, further research is still needed.

In general terms, the use of the three-point static bending test appears as an alternative way to determine the longitudinal modulus of elasticity of round timber structural beams, since it imposes less operational difficulties than those of the cantilever beam clamped model, as proposed by the Brazilian standard[2].

The ratio $L / D_{e q} \geq 21[23]$ allows to use the Euler Bernoulli beam theory to calculate the deflections with no shear effect which were used to determine the modulus of elasticity. In addition it was possible to use the three point bending test, even when shear efforts exist at the applied load.

The restriction of displacements (L/200 and L/300) provide the use of non-destructive methodology to determine the longitudinal modulus of elasticity of timber beams, instead of the Brazilian standard[6] which is based on a destructive method using small sample size.

\section{REFERENCES}

[1] A. L. Christoforo, T. H. Panzera, F. B. Batista, P. H. Borges, F. A. Rocco Lahr, " Numerical Evaluation of the Longitudinal Modulus of Elasticity in Structural Round Timber Elements of Eucalyptus genus", Agricultural Engineering Journal, v. 31, p. 1009-1016, 2011

[2] Associação Brasileira de Normas Técnicas - NBR 6231, "Postes de madeira-resistência à flexão", Rio de Janeiro, 1980.

[3] Associação Brasileira de Normas Técnicas - NBR 8456, "Postes de eucalipto preservado para redes de distribuição de energia elétrica", Rio de Janeiro, 1984.

[4] Associação Brasileira de Normas Técnicas - NBR 8457 , "Postes de eucalipto preservado para redes de distribuição de energia elétrica: dimensões", Rio de Janeiro, 1984.

[5] Associação Brasileira de Normas Técnicas - NBR 6122, "Projeto e execução de fundações", Rio de Janeiro, 1996.

[6] Associação Brasileira de Normas Técnicas - NBR 7190, "Projeto de estruturas de madeira", Rio de Janeiro, 1997.

[7] American National Standards Institute - ANSI O5.1, "American national standard for wood poles", Washington, DC. 2002.

[8] American Society for Testing and Materials - ASTM D198, "Static tests of timbers in structural sizes", Philadelphia, PA. 1976.

[9] American Society for Testing and Materials - ASTM D1036, "Standard test methods of static tests of wood poles", Philadelphia, PA. 1997.

[10] Comité Européen de Normalisation - DIN EN 14251, "Structural round timbers: test methods", Bruxelas, Bélgica. 2004.

[11] Australian Standard - AS 2209, "Timber-poles for overheads lines", Australia, 1994.

[12] A. Ranta-Maunus, "Bending and compression properties of small diameter round timber", In: World Conference on Timber Engineering, Whistler, Canada, 2000.

[13] R. Wolfe, C. Moseley, "Small-diameter log evaluation for value-added structural applications", Forest Products Journal, Madison, v.50, p. 48-58, 2000.

[14] R. J. Ross, X. Wang, J. A. Mattson, J. R. Erickson, J. W. Forsman, E. A. Geske, M. A. Wehr, "Comparison of several nondestructive evaluation techniques for assessing stiffness and MOE of small-diameter logs", Research Paper. Madison, WI: U. S., Department of Agriculture, Forest Service, Forest Products Laboratory, 2001.

[15] C, Calil Jr, M. M. Espinosa, A. J. S. Miná, A. A. Dias, "Confiabilidade em elementos estruturais de madeira roliça", Revista madeira (CD-Rom), São Carlos, v. 14, 2004.

[16] J. Pinto Neto, C. Calil Jr., M. M. Espinoza, "Propriedades de resistência e rigidez de peças estruturais roliças de pequeno diâmetro", In: IX Encontro Brasileiro em Madeiras e em Estruturas de Madeira. Cuiabá, MT, 2004.

[17] A. Sales, T. R. Pelizan, F. G. R. Oliveira, M. Candian, F. F. Lucchette, J. L. Salgon, K. P. Miller, "Avaliação de pro- 
priedades mecânicas de peças roliças de Eucalipto por meio de ultra-som", In: IX Encontro Brasileiro em Madeiras e em Estruturas de Madeira. Cuiabá, MT, 2004.

[18] D. Larson, R. Mirth, R. Wolfe, "Evaluation of small-diameter ponderosa pine logs in bending", Forest Products Journal, Madison, WI, v.54, p.52-58, 2004.

[19] A. J. S. Miná, A. A. Dias, "Estacas de madeira para fundações de pontes de madeira", Cadernos de Engenharia de Estruturas (Online), v. 10, p. 129-155, 2008.

[20] M. R. Carreira, A. A. Dias, "Avaliação da rigidez à flexão de toras de madeira por meio de vibração transversal", Cadernos de Engenharia de Estruturas (Online), v. 11, p. 75-79, 2009.

[21] A. Sales, M. Candian, V. C. Salles, "Nondestructive evaluation of timber: the new Brazilian code for the design of timber structures", Materials and Structures, v. 43, p. 213-221, 2010.

[22] A. J. S. MINÁ, "Estudo de estacas de madeira para fundações de pontes de madeira", Tese (Doutorado em Engenharia de Estruturas), 117 p, Escola de Engenharia de São Carlos, Universidade de São Paulo, São Carlos, 2005.

[23] A. L. Zangiácomo, F. A. Rocco Lahr, "Avaliação do efeito de cisalhamento na flexão de elementos roliços da espécie Eucalyptus citriodora", In: XI EBRAMEM - Encontro Brasileiro em Madeiras e em Estruturas de Madeira, Londrina, PR, 2008.

[24] A. J. S. Miná, A. A. Dias, C. Calil Jr., "Avaliação da rigidez e da resistência de postes de madeira para uso como estacas para fundações", In: IX Encontro Brasileiro em Madeiras e em Estruturas de Madeira, Cuiabá, MT, 2004.

[25] F. G. R. Oliveira, A. Sales, "Ultrassonic measurements in Brazilian hardwood", Materials Research, v. 5, n. 1, p. 51-55, 2002.

[26] V. Wolfe, "Research challenges for structural use of small-diameter round timbers". Forest Products Journal, v. 50, n. 2, p. 21-29, 2000.

[27] X. Wang, R. J. Ross, M. McLellan, R. J. Barbour, J. R. Erickson, J. W. Forsman, G. D. McGinnis. "Nondestructive evaluation on standing trees with a stress wave method". Wood and Fiber Science, v. 33, n. 4, p. 522-533, 2001.
[28] W. M. G. Burdzik, P. D. Nkwera, "Transverse vibration tests for prediction of stiffness and strength properties of full size Eucalyptus grandis". Forest Products Journal, v. 52, n. 6, p. 63-67, 2002.

[29] X. Wang, R. J. Ross, J. A. Mattson, J. R. Erickson, J. W. Forsman, E. A. Geske, M. A. Wehr, "Nondestructive evaluation techniques for assessing modulus of elasticity and stiffness of small-diameter logs". Forest Products Journal, v. 52, n. 2, p. 79-85, 2002.

[30] X. Wang, R. J. Ross, B. K. Brashaw, J. Punches, J. R. Erickson, J. W. Forsman, R. Pellerin, "Diameter effect on stress-wave evaluation of modulus of elasticity of logs". Wood and Fiber Science, v. 36, n. 3, p. 368-377, 2004.

[31] R. Wolfe, J. Murphy, "Strength of small-diameter round and tapered bending members". Forest Products Journal, v. 55, n. 3 , p. 50-55, 2005.

[32] S. Y. Wang, J. H. Chen, M. J. Tsai, C. J. Lin, T. H. Yang, "Grading of softwood lumber using non-destructive techniques". Journal of Materials Processing Technology, v. 208, p. 149-158, 2008.

[33] J. Xiao, C. Sa., Y. Han, "Nondestructive Testing of Dynamic Elastic Modulus of Wood-Basedpanel by the Method of Stress Wave". Proceedings of the 9th International Conference on Electronic Measurement and Instruments ICEMI, Vol.2, Beijing, China, pp. 357-361, 2009.

[34] M. Yamasaki, Y. Sasaki, "Determining Young's modulus of timber on the basis of a strength database and stress wave propagation velocity I: an estimation method for Young's modulus employing Monte Carlo simulation". Journal of Wood Science, v. 56, n. 4, p. 269-275, 2010.

[35] A. Sales, M. Candian, V. S. Cardin, "Evaluation of the mechanical properties of Brazilian lumber ( Goupia glabra) by nondestructive techniques". Construction and Building Materials, v. 25, n. 3, p. 1450-1454, 2011.

[36] M. C. C. Werkema, S. Aguiar, "Planejamento e análise de experimentos: como identificar e avaliar as principais variáveis influentes em um processo", Belo Horizonte: Fundação Christiano Ottoni, Escola de Engenharia da Universidade Federal de Minas Gerais, 1996. 